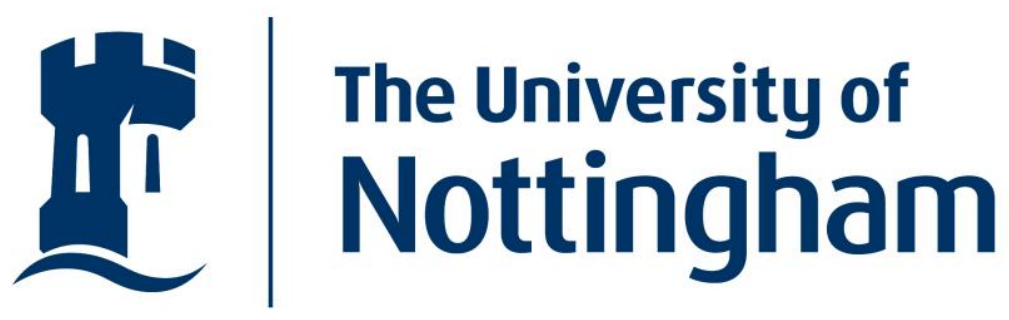

UNITED KINGDOM • CHINA • MALAYSIA

Discussion Papers in Economics

Discussion Paper

No. $15 / 02$

Do Poverty Reduction Strategy Papers reduce poverty and improve well-being?

Meg Elkins, Simon Feeny \& David Prentice

February 2015 


\title{
Do Poverty Reduction Strategy Papers reduce poverty and improve well-being?
}

\author{
Elkins, Meg* ${ }^{1}$, Feeny, Simon $^{1} \&$ Prentice, David ${ }^{2}$. \\ School of Economics, Finance and Marketing, RMIT University, Melbourne, Australia ${ }^{1}$ \\ School of Economics, University of Nottingham - Malaysian Campus, Semenyih, Malaysia ${ }^{2}$
}

\begin{abstract}
With almost 15 years passing since their introduction, quantitative evaluations of Poverty Reduction Strategy Papers (PRSPs) have been surprisingly sparse. This paper examines whether a PRSP impacts on poverty reduction and well-being and whether PRSP alignment to development paradigms impacts upon the achievement of these outcomes. Specifically, it estimates the causal effect of having a PRSP on various targets of the United Nations' Millennium Development Goals. The sample is composed of a treatment group consisting of 51 developing countries undertaking PRSPs and 62 control countries determined through propensity score matching techniques, over the period 1999 to 2008. Results suggest that countries under PRSP treatment have achieved better well-being outcomes than those in the control group. PRSP alignment to different development paradigms is also shown to matter.
\end{abstract}

Keywords: MDGs; PRSPs; programme evaluation; poverty reduction; well-being

\footnotetext{
*Acknowledgements: The authors would like to thank Bob Baulch, Laura Camfield, and Alberto Posso for their helpful comments and advice, as well as conference participants from both the European Association of Development Research and Training Institute (EADI) conference June 23-26, 2014 (Bonn, Germany ) and at the Development Economics Forum July 4-5, 2014 (Ho Chi Minh, Vietnam)

*Corresponding author at: School of Economics, Finance and Marketing, RMIT University, Level 11445 Swanston St, Melbourne, VIC 3000, Australia. Tel.: +61 39925 1547; fax: +61 399255986.

E-mail address: meg.elkins@rmit.edu.au
} 


\section{INTRODUCTION}

The introduction of the World Bank's Poverty Reduction Strategy Papers (PRSPs) in September 2000 promised a new focus on poverty reduction with national ownership driving the process. PRSPs were introduced to provide the strategic framework for developing countries to devise economic and social policies dedicated to multidimensional poverty reduction. The scope of PRSPs quickly broadened to include a road map of how a country intends to achieve the United Nations' Millennium Development Goals (MDGs), encapsulating not only income poverty reduction but other well-being outcomes. The MDGs and PRSPs collectively demonstrated a renewed importance that donor organisations placed on tackling poverty in its many forms. With almost 15 years passing since their introduction, quantitative evaluations of PRSP effectiveness are surprisingly sparse. Given the importance that international donors place on PRSPs and the resources that are required for their compilation and implementation, an investigation into their outcomes is clearly warranted.

This paper examines the impact of PRSPs on reducing income poverty and on progress towards other MDGs. Specifically, two research questions are addressed by the paper. Firstly, do PRSP adopters achieve better progress towards MDG targets and poverty reduction than non-adopting countries? Secondly, does the alignment of PRSP policies to a dominant development paradigm influence progress towards these development goals? We use data on the performance of countries against seven targets of the Millennium Development Goals. The sample includes 52 countries which adopted PRSPs and 65 control countries to determine whether having a PRSP improves country 
performance in progressing towards these goals. Treatment effects are modelled both as being homogenous and as heterogeneous, being a function of the alignment of the PRSP to each of four development paradigms, as discussed in more detail below. Propensity Score Matching (PSM) is used to create the control group.

The results from the analysis are very encouraging for the international community: PRSP adoption is found to lead to a number of superior development outcomes. Results suggest that PRSP adoption leads to greater reductions in headcount poverty, infant mortality and HIV prevalence. Increases in primary school enrolments, the ratio of girls to boys in primary school enrolments and access to sanitation are also higher for PRSP adopters. Results also reveal that the policy content of PRSPs matters for progress towards MDG targets. For example, PRSPs that have policies aligned to the New York Consensus had significantly better progress on a range of indicators.

The remainder of this paper is structured as follows. Section 2 provides the background and motivation for the investigation as well as summarising the relevant academic literature. Section 3 describes the data and the methodology to determine the control group of non-PRSP adopting countries. Section 4 presents the results from the estimation of the empirical models. Finally, Section 5 concludes.

\section{Background, Motivation and Literature Review}

A PRSP is a document prepared by a developing country government under the guidance of the World Bank and International Monetary Fund (IMF). Typically, a PRSP identifies the incidence and causes of poverty and determines specific strategies and policies to reduce poverty, including expenditure targets. PRSPs should represent the 
consensus views of various stakeholders and targets within PRSPs can be aspirational, highlighting deficiencies that a country would like to overcome rather than reflecting an ability to achieve such changes. The PRSP framework is intended to be locally owned and generated and developed through a wide participatory dialogue with civil society (Kamruzzman, 2009). Goal setting, budget requirements and monitoring and evaluation ensure government commitment through implementation (Eggen and Bezemer, 2008).

The advent of PRSPs coincided with a new global commitment to reduce poverty in its many forms. In September 2000, the 189 United Nation member states signed the Millennium Declaration committing them to the achievement of the MDGs by 2015. Using 1990 as a baseline, the global goals address several dimensions of well-being including (i) eradicating extreme poverty and hunger; (ii) achieving universal primary school education; (iii) promoting gender equality; (iv) reducing child mortality; (v) improving maternal mortality (vi) combatting HIV/Aids, malaria and other infectious diseases (vii) ensuring environmental sustainability; (viii) and developing global partners for global development (UNDP., 2005). Since there is a lack of a consensus regarding the practicalities of how these goals should be achieved, the MDGs are integrated into countries PRSPs (Fukuda-Parr, 2003). The United Nations became goal setters of the MDG process and the World Bank adopted a role to assist with the implementation programmes required to achieve the goals through PRSPs (Hulme and Scott, 2010).

There are few existing academic studies that evaluate the impact of PRSPs on poverty reduction. Marshall and Walters (2011) assess whether the incidence of income poverty, per capita income levels and the degree of inequality are associated with PRSP adoption. A control group is determined through propensity score matching, and 3| P a g e 
treatment effects are estimated using panel data techniques that are replicated in this paper. Marshall and Walters (2011) find evidence that income poverty reduction is greater for countries with a PRSP. The study only assesses whether or not PRSP adoption is associated with better outcomes for poverty levels, per capita income and inequality, but fails to account for policy differences or heterogeneity within PRSPs.

A second quantitative evaluation is that of Eggen and Bezemer (2008). The study regresses selected MDG health and education indicators on explanatory variables that include PRSP adoption, PRSP policy quality, the existence of goal setting, the speed of conversion from an interim PRSP to a full PRSP and the time duration covered by the PRSP. They find that PRSPs are important in determining progress towards increasing rates of immunisation and school enrolment but not in improving rates of infant mortality and literacy and increasing gender equality. PRSPs that had a longer lead time between interim PRSPS and full PRSPS were found to achieve better outcomes for child health targets, and countries with a PRSP that specified clear goals achieved better outcomes for educational targets. However, this study suffers from a very small sample size. Only 17 PRSPs are examined, and it only focuses on agricultural policies in its content evaluation.

The approach of evaluating the effects of PRSPs, as adopted in these studies, is complicated by differences between them that can be expected to arise given the principles of country ownership and civil society involvement in their design. One way to characterise the differences in PRSPs is in terms of their alignment to four contemporary development paradigms: the Washington Consensus (WC); the Post Washington Consensus (PWC); the New York Consensus (NYC); and the Social Protection Agenda (SP). The Washington Consensus (WC) features policies to liberalise, privatise and deregulate 4 I P a g e 
(Williamson, 1990, Williamson, 1993, Marangos, 2009). The Post Washington Consensus (PWC) is based on a second generation of WC reforms to create quality institutions, regulate structures based on cautious global integration and provide social safety nets (Rodrik, 2006, Stiglitz., 1998, Mosely, 2001). The New York Consensus (NYC) embodies the policies and intent of the United Nation's Millennium Declaration. It is built on economic growth, aid, targeted government expenditure and good governance, with the eventual aim of MDG attainment (Sumner, 2006, UNDP., 2005). The fourth development paradigm, the social protection agenda, is represented by policies and programs directly aimed at reducing poverty and vulnerability (Deveraux and Sabates-Wheeler, 2004, Baulch and Wood, 2008, Elkins, 2014, Baulch, 2006, Farrington, 2006)

The PWC and NYC were designed to counter the WC policies that failed to deliver on the poverty reduction promise (Stiglitz, 1998, Sumner, 2006). The Post-Washington Consensus was not always fully embraced as a development paradigm, but more as a series of second generation WC reforms (Fine, 2002, Rodrik, 2006, Saad-Filho, 2007). Despite becoming dominant in policy circles, intellectually the proponents of the NYC have not been able to garner the same level of academic support as established by the economic orthodoxy of the WC (Hulme and Scott, 2010). The recent global economic crisis which followed large hikes in the prices of both food and fuel increased the incidence of global poverty, highlighted the issue of vulnerability and has led to a resurgence in support for the SP paradigm.

Another strand of the PRSP literature examines the policy content of PRSPs while neglecting the question of whether they have an impact on well-being outcomes (Gottschalk, 2005, Ikhide and Obandan, 2011, Stewart and Wang, 2003, Sumner, 2006, 5 | P a g e 
Fukuda-Parr, 2010). These studies generally hold the view that there is little variation in PRSP policies across countries. Gottschalk (2005) analyses the variation of macroeconomic content with the PRSPs and is critical of the lack of variation and the absence of policies for developing countries' capacity to respond to shocks and macroeconomic volatility. Stewart and Wang (2003) review the policy content with a focus as to whether country 'ownership' has increased as a result of the PRSP process. Although noting a rise in policies outlining governance, public sector management and poverty reduction, the study concluded that the similarity of the macroeconomic programmes of the countries evaluated suggests that PRSPs are more 'window dressing' than signifying true national ownership and civil society participation. Sumner (2006) examines 450 policies in PRSP and finds that only 11 policies can be classified as unconventional. In summary, the study finds a full alignment to the WC is no longer the norm, but the shift to a contemporary development paradigm is far from complete. Fukuda-Parr (2010) evaluates the content of PRSPs and demonstrates a clear commitment to achieving education, health and water targets but a lack of priority in the areas of gender equality and gender empowerment goals.

In reviewing PRSP content evaluations it is evident that later studies find greater policy diversity than those initial studies undertaken closer to their introduction. A more recent study by Elkins and Feeny (2014) provides the most comprehensive evaluation of PRSPs policy content to-date. It finds that the NYC, which was forged around the MDGs, is driving the content of PRSPs. While this might reflect a requirement for PRSPs to operationalise the MDGs, the claim that WC policies dominate policy space in PRSPs is no longer the case, giving rise to a new contemporary development agenda. 
The issue of participation in the PRSP process is of interest to several studies as it is ownership and participation that creates diversity in the policy sets within PRSPs. Previous studies (Booth, 2005, Cornwall and Brock, 2005, Kamruzzman, 2009, Lazarus, 2008, Dijkstra, 2005) identify a disconnect between the PRSPs and participation. Other studies are less critical of the PRSP process (Cheru, 2006, Driscoll and Evans, 2005).

The current paper builds on the existing literature by utilising additional data and examining whether the alignment of a PRSP to a development paradigm is important (in addition to the adoption of a PRSP) in determining progress towards the achievement of the MDGs.

\section{Data AND Methodology}

This paper examines the impact of PRSP adoption on poverty and well-being outcomes, allowing for homogenous treatment effects and heterogeneous treatment effects that vary with the alignment of each PRSP to the four development paradigms. The unit of observation is the country by year. A dataset comprising an unbalanced panel of 117 countries for the period 1999 to 2008 is utilised.

The research involves an extensive review of each country's PRSP. The PRSPs are sourced from the World Bank's Board Presentations of Country-owned PRSPs (as of Feb 29, 2012). ${ }^{1}$ The impact of PRSPs on progress towards seven MDG target variables is analysed. These variables are commonly used in the development literature due to data availability and their capacity to explain progress on the original tenets of the Millennium

\footnotetext{
${ }^{1}$ http://siteresources.worldbank.org/INTPRS1/Resources/boardlist.pdf
} 
Declaration (Leo and Barmeier, 2010) ${ }^{2}$. Variable definitions and their sources are provided in Table $A 1$ in the appendix.

The analysis is conducted in three stages: (1) the evaluation of the policy content of PRSPs and their alignment to dominant development paradigms; (2) the use of PSM to create a valid control group to include in the sample with the treatment group (countries which adopted a PRSP); and (3) the estimation of a difference-in-difference model to identify the determinants of differences in progress towards MDG target variables between the treatment and control groups. Each stage is discussed in turn.

\subsection{Paradigm alignment indices}

The paradigm alignment indices are calculated for all PRSP adopting countries. The alignments of each PRSP are judged by comparing its policy content to the policies advocated by each development paradigm. These policies are provided in Tables A2 to A5 in the appendix. There are 19 Washington Consensus policies, 17 Post Washington Consensus policies, 22 New York Consensus policies and 24 social protection policies. For further explanation of how the WC, PWC and NYC indices are constructed see Elkins and Feeny (2014). For the derivation of the social protection index refer to Elkins (2014). A scorecard approach is adopted which provides a quantitative evaluation of PRSP policy content, previously used by Bojo and Reddy (2002), Eggen and Bezemer (2008) and Sapkota (2011). Although the method involves subjective judgments it is considered sufficiently reliable to provide transparent judgments to evaluate policies that determine paradigm alignment in the PRSP, by condensing information in a practical way that allows

\footnotetext{
${ }^{2}$ Leo and Barmeier (2010) uses additional measures of under-nourishment prevalence rate and uses percentage of the population with access to improved water sources, rather than access to sanitation. 8 I P a g e
} 
for clear interpretation. The text of each country's PRSP is checked against whether each policy is mentioned and, if so, to what extent. Each PRSP receives a score of zero to three for each policy (see Table 1 below). Higher scores reflect a greater degree of policy adoption and, therefore, greater alignment to the paradigm.

Table 1: PRSP scorecard system

\begin{tabular}{ll}
\hline Score & Criteria \\
\hline 0 & No mention of the policy \\
1 & Policy is mentioned \\
2 & Policy is elaborated upon \\
3 & Policy is extensively elaborated upon \\
\hline
\end{tabular}

All individual PRSP policy scores are then summed and re-scaled to create an overall paradigm alignment index value. Each index value falls between 0 and 1 to ensure scale equivalence. The following formula is used:

PRSP alignment index jk $_{k}=\frac{\sum \text { Policy Score } i_{j k}}{\text { Policy Score } \text { Max }_{k}}$

where $i=$ policy,$j=$ country and $k=$ paradigm.

\subsection{Propensity score matching}

To include a control group in the regression sample, PSM is adopted, following the approach of Heckman et al. (1997). PSM is used so to find countries with similar characteristics to those that adopted a PRSP but which chose not to. While one approach would have been to use all developing nations not participating in the PRSP process, this is not taken since the original focus of the PRSP program was Heavily Indebted Poor Countries (HIPCS). Moreover, some countries such as Albania and Armenia voluntarily participated in the PRSP process in the hope of improving their economy and reducing poverty. Although the two stage process of constructing a sample by propensity scores 
prior to estimating a model is recent (Angrist and Pischke, 2009, Chabé-Ferret, 2015, Clump et al., 2009, Imbens and Wooldridge, 2009, Lechner, 2010) an increasing number of studies have adopted this approach (Hijzen et al., 2013, Hijzen et al., 2010, Hong, 2013, Machin et al., 2010).

To generate the propensity scores, we estimate a probit model of the probability of receiving PRSP treatment on a cross-section of 121 developing countries. Following the approach of Caliendo and Kopeining (2008) explanatory variables are chosen that influence the decision to participate as well as progress towards MDG targets. Average values for between 1996 and 1999 are used so to remove the effects of cyclical and atypical variations.

The selection process uses the radius matching technique (with replacement) that chooses the nearest match propensity score within a calliper of 0.17 . Using this method reduces the possible bias. However, it also decreases the number of matches available as poor matches are excluded. Four treatment countries without appropriate matches are excluded from the sample. ${ }^{3}$

The probit estimation results are presented in Table $A 6$ of the appendix and conform to expectations regarding the effects of the explanatory variables on PRSP adoption. The results reveal a positive association with external debt to $\mathrm{GNI}$ and a negative association with GDP per capita and ethnic diversity.

\footnotetext{
${ }^{3}$ These countries were Bosnia-Herzegovina, Guinea-Bissau, Liberia and Mozambique. Note though that we found our main results were not sensitive to small changes in the number of countries.
} 
The propensity score matching process results in the selection of 52 treatment countries and 65 control countries (see Table A7 in the appendix for a list of these countries). ${ }^{4}$ As evidence of the validity of the selection process, all countries that commenced PRSP treatment after the year 2008 are included as matches for the control group $^{5}$. The control group also includes matches from countries that undertook the first stage interim PRSP, but never progressed to the final full PRSP.

Descriptive statistics are presented in Tables A8 and A9 in the appendix. The data are organised into two groups: the treated countries and the control countries. It should be noted that there is a large variation in the availability of data for the MDG target variables. Maternal mortality and headcount poverty have the least available observations; therefore the results for these indicators must be taken with a degree of caution as they may be skewed towards explaining the outcomes of the countries which have the requisite data.

With respect to the data presented in Tables A8 and A9 in the appendix, $t$-tests demonstrate statistically significant differences in the means of the variables for the treatment and control groups. Specifically, treatment countries tend to perform poorer across the MDG targets compared to the control countries. It is important to note that although using propensity scores enables assigning a causal interpretation to the effect of receiving the PRSP this cannot be done with respect to the assignment of the paradigm

\footnotetext{
${ }^{4}$ In addition to the four off-support countries, two countries, Afghanistan and Timor-Leste, were not able to be matched due to a paucity of data in the pre-treatment period.

${ }^{5}$ Central African Republic, Republic of Congo, and Cote D'lvoire, which were all selected in the control group, undertook a PRSP after 2008. Indonesia, Grenada and Macedonia which never progressed beyond the Interim PRSP stages were also matched in the control group.
} 
alignment indices. It is not possible to artificially create randomisation with respect to the contents of PRSPs.

\subsection{Difference in difference modelling}

Following the construction of a control group the following model is estimated for the sample to yield estimates of homogenous treatment effects (the impact on progress towards the MDGs of adopting a PRSP):

$Y_{i t}=\beta_{0}+\beta_{1} P R S P_{i t}+\beta_{3} X_{i t}+\alpha_{i}+\delta_{t}+\varepsilon_{i t}$

where $Y_{i t}$ is the MDG target variable for the country $(i)$ in year $(t) ; P R S P_{i t}$ is a dummy variable taking the value of 1 for the years during which a country adopted a PRSP; $X_{i t}$ is a vector of control variables; $\alpha_{i}$ are country-specific fixed effects; $\delta_{t}$ are year fixed effects and $\varepsilon_{i t}$ is an error term. Once a country commences PRSP treatment it is assumed that this treatment is on-going for the entire period up to 2008. Burundi, for example, commenced PRSP treatment in 2006, so the treatment indicator is switched on for the period 2006-2008. In this model, the coefficient of interest is $\beta_{1}$ which gives the treatment effect of adopting a PRSP.

A second model allows for heterogeneous treatment effects. Specifically, as different PRSPs are influenced to different degrees by four development paradigms, we model the treatment effect as a function of the paradigm alignment index scores for each paradigm, as in Equation (3): 


$$
Y_{i t}=\beta_{0}+\beta_{1} \text { PRSP }_{i t}+\sum_{k=1}^{4} \beta_{2 k} \operatorname{PRSP}_{i t} * P A I S_{i k t}+B_{3} X_{i t}+\alpha_{i}+\delta_{t}+\varepsilon_{i t}^{\prime}
$$

where $P A I S_{i k t}$ is the paradigm alignment score for paradigm $k$ for country $i$ at time $t$. The paradigm alignment score is allowed to vary over time as some countries have two PRSPs, with different characteristics, during the sample period. The average treatment effect is given by:

$\beta_{1}+\sum_{k=1}^{4} \beta_{2 k} P A I S_{i k t}$

The coefficients on each $P A I S_{i k t}$ indicate the importance of alignment to a particular paradigm in achieving progress towards the MDG targets. Following previous studies, the vector of control variables in equations (2) and (3), $X_{i t}$, includes GDP per capita; a measure of governance and health expenditure as a percentage of GDP for health related MDGs. Further details are provided in Table A1 of the appendix.

\section{RESULTS AND INTERPRETATION}

The model is estimated for seven MDG targets using a ten year unbalanced panel from 1999-2008 for up to 117 countries (52 treatment countries and 65 control countries). Sample size varies according to the MDG target under consideration. There are two specifications for each of the seven indicators. The first model relating to equation (2) assumes a homogeneous PRSP treatment effects. The second specification relating to equation (3) determines PRSP treatment with heterogeneous treatment effects as it includes the paradigm alignment indices. All results are reported in Table 2.

The primary result is that PRSPs result in statistically significant improvements in performance in achieving all of the MDG targets except for maternal mortality. This result 
occurs whether homogeneous or heterogeneous treatment effects are assumed. Indeed, comparing the coefficient on PRSP treatment for the homogeneous effects specification with the average treatment effect (on the treated) for the heterogeneous treatment effects specification (reported below the coefficients in Table 2) reveals the size of the effects are similar in most cases. One possible reason for the anomalous result for maternal mortality is that the sample size is small relative to the number of coefficients being estimated, resulting in the model fitting the data too specifically. All discussion that follows focuses on the results excluding maternal mortality unless stated otherwise.

We assess the size of the effect of the PRSP treatment by comparing the estimated treatment effects with the coefficient on the year dummy for 2008. As the omitted year-class is 1999, the size of this coefficient is an estimate of the average progress that would have been made in the absence of PRSP treatment. This coefficient is referred to as the trend outcome. The average effects from having a PRSP are substantial and typically did not vary much across the two specifications. For all except two MDG targets, the improvement in performance from having a PRSP is between 25 per cent and 50 per cent of the trend outcome. The two exceptions are sanitation and HIV prevalence. The improvement in sanitation was just 13-14 per cent of the trend outcome whereas the improvement in performance for HIV prevalence was 80 per cent for the homogeneous treatments specification and 90 per cent for the heterogeneous treatments specification. While a complete assessment of the PRSP program would need to take into the costs of achieving these outcomes, the results in Table 2 suggest that in all cases countries with PRSPs performed both significantly and substantially better than those without over this period for nearly all of the MDG targets. 
Next, the results of allowing for heterogeneous treatment effects are considered. To determine whether allowing for heterogeneous treatment effects improved the performance of the specification, in the row below that of the average treatment effects, the results of a set of F-tests of the joint significance of the interaction terms are reported. For all the MDG targets, the interaction terms are jointly statistically significant at 10 per cent. For head count poverty and infant mortality, the test statistics have pvalues of around 7.7 per cent whereas for the remaining four MDG targets, the p-values are at most 2.8 per cent. This suggests that allowing for heterogeneous treatment effects significantly improves the performance of the specifications of most of the MDG targets. While we cannot assign causal effects of the paradigm alignment, some interesting features do emerge. First, is that if an interaction term is statistically significant it is nearly always at least 150 per cent of the size of the average treatment effect. Secondly, among the four paradigms, the NYC is most frequently statistically significant and the effects are almost always in the direction of improving the performance of the PRSP. The only exceptions are for sanitation where the sign is incorrect and headcount poverty, where the coefficient is insignificant. The social protection index is significant for four of six MDG targets, having the expected effects on headcount poverty and sanitation but opposite effects on primary school enrolments and gender equity. As the SP is pro-poor in its agenda, these associations with the headcount poverty suggests the policies aligning to social protection policies in the PRSP are serving to fulfil the desired objectives of income poverty reduction. The WC alignment index is significant for three of the targets, having expected effects on gender equity and sanitation but a counter-intuitive effect on headcount poverty. The PWC index is also significant for three of the targets but its sign is 
always opposite to what is expected. Finally, the control variables are discussed. Per capita GDP is frequently statistically significant but always with a negative effect on performance. This suggests a selection effect may be going on. Countries with higher per capita GDP find it harder to make improvements in achieving improvements in the MDG targets. Evidence suggests that Middle-Income Countries (MIC) are already achieving MDG targets (Fukuda-Parr, 2013, Kenny and Sumner, 2011, Klasen and Lange, 2012, Vandemoortele., 2009). This is due to the initial starting levels of these indicators being at high levels pre-treatment. Governance is typically statistically insignificant whereas health expenditure is usually significant and has the expected sign. 
Table 2: Fixed Effects Estimator of MDG Indicators 1999-2008

\begin{tabular}{|c|c|c|c|c|c|c|c|c|c|c|c|c|c|c|}
\hline \multirow{2}{*}{ VARIABLES } & \multicolumn{2}{|c|}{$\begin{array}{c}\text { Head count Poverty } \\
\text { Goal } 1\end{array}$} & \multicolumn{2}{|c|}{$\begin{array}{c}\text { Primary School Enrol } \\
\text { Goal } 2\end{array}$} & \multicolumn{2}{|c|}{$\begin{array}{c}\text { Male to Female Ratio } \\
\text { Goal } 3\end{array}$} & \multicolumn{2}{|c|}{$\begin{array}{l}\text { Infant Mortality } \\
\text { Goal } 4 \\
\end{array}$} & \multicolumn{2}{|c|}{$\begin{array}{c}\text { Maternal Mortality } \\
\text { Goal } 5 \\
\end{array}$} & \multicolumn{2}{|c|}{$\begin{array}{l}\text { HIV Prevalence } \\
\text { Goal } 6\end{array}$} & \multicolumn{2}{|c|}{$\begin{array}{c}\text { Access to Sanitation } \\
\text { Goal } 7\end{array}$} \\
\hline & (1) & (2) & (3) & (4) & (5) & (6) & (7) & (8) & (9) & (10) & (11) & (12) & (13) & (14) \\
\hline PRSP treatment & $\begin{array}{c}-4.020^{\star \star \star} \\
(-3.73)\end{array}$ & $\begin{array}{l}-1.241 \\
(-0.61)\end{array}$ & $\begin{array}{c}2.546^{\star \star \star} \\
(3.77)\end{array}$ & $\begin{array}{c}5.653^{\star * *} \\
(3.65)\end{array}$ & $\begin{array}{c}1.833^{\star \star \star} \\
(5.99)\end{array}$ & $\begin{array}{c}2.431^{* * *} \\
(4.06)\end{array}$ & $\begin{array}{c}-3.030^{\star * *} \\
(-8.16)\end{array}$ & $\begin{array}{c}-2.140^{* * *} \\
(-2.79)\end{array}$ & $\begin{array}{l}-31.986 \\
(-1.45)\end{array}$ & $\begin{array}{c}-163.133^{* \star *} \\
(-2.88)\end{array}$ & $\begin{array}{c}-0.165^{\star \star *} \\
(-3.40)\end{array}$ & $\begin{array}{c}-0.304^{\star * *} \\
(-3.21)\end{array}$ & $\begin{array}{c}0.643^{\star * \star} \\
(2.59)\end{array}$ & $\begin{array}{l}0.534 \\
(1.05)\end{array}$ \\
\hline $\begin{array}{l}\text { Per Capita GDP } \\
2005\end{array}$ & $\begin{array}{c}0.796^{* *} \\
(2.31)\end{array}$ & $\begin{array}{c}0.833^{\star *} \\
(2.41)\end{array}$ & $\begin{array}{c}-2.403^{\star \star \star} \\
(-8.03)\end{array}$ & $\begin{array}{c}-2.141^{* * *} \\
(-7.27)\end{array}$ & $\begin{array}{c}-0.928^{\star * *} \\
(-7.31)\end{array}$ & $\begin{array}{c}-0.842^{\star * \star} \\
(-6.69)\end{array}$ & $\begin{array}{c}0.733^{\star \star \star} \\
(4.65)\end{array}$ & $\begin{array}{c}0.701^{\star \star \star} \\
(4.42)\end{array}$ & $\begin{array}{l}7.881 \\
(1.30)\end{array}$ & $\begin{array}{l}8.080 \\
(1.35)\end{array}$ & $\begin{array}{c}0.102^{\star \star \star} \\
(5.03)\end{array}$ & $\begin{array}{c}0.096^{\star \star \star} \\
(4.71)\end{array}$ & $\begin{array}{l}-0.045 \\
(-0.42)\end{array}$ & $\begin{array}{l}-0.072 \\
(-0.67)\end{array}$ \\
\hline Governance & $\begin{array}{l}0.030 \\
(0.10)\end{array}$ & $\begin{array}{l}-0.040 \\
(0.13)\end{array}$ & $\begin{array}{l}0.282 \\
(1.26)\end{array}$ & $\begin{array}{l}0.128 \\
(0.59)\end{array}$ & $\begin{array}{l}-0.137 \\
(-1.42)\end{array}$ & $\begin{array}{l}-0.169^{\star} \\
(-1.78)\end{array}$ & $\begin{array}{c}-0.237^{\star *} \\
(2.05)\end{array}$ & $\begin{array}{l}-0.232^{* *} \\
(-2.00)\end{array}$ & $\begin{array}{c}-42.965^{\star \star *} \\
(-6.46)\end{array}$ & $\begin{array}{c}-40.652^{* * *} \\
(-5.99)\end{array}$ & $\begin{array}{l}-0.019 \\
(-1.20)\end{array}$ & $\begin{array}{l}-0.013 \\
(-0.79)\end{array}$ & $\begin{array}{l}-0.166^{\star *} \\
(-2.12)\end{array}$ & $\begin{array}{l}-0.164^{* *} \\
(-2.11)\end{array}$ \\
\hline Health as \%GDP & $\begin{array}{c}-0.875^{\star \star *} \\
(-2.82)\end{array}$ & $\begin{array}{c}-0.863^{\star \star \star} \\
(-2.81)\end{array}$ & & & & & $\begin{array}{c}-0.597^{\star \star *} \\
(-4.92)\end{array}$ & $\begin{array}{c}-0.597^{\star \star *} \\
(-4.91)\end{array}$ & $\begin{array}{l}4.224 \\
(0.62)\end{array}$ & $\begin{array}{l}1.158 \\
(0.17)\end{array}$ & $\begin{array}{c}-0.049^{\star * *} \\
(-3.20)\end{array}$ & $\begin{array}{c}-0.051^{* * *} \\
(-3.32)\end{array}$ & & \\
\hline Interaction WC & & $\begin{array}{l}9.793^{*} \\
(1.84)\end{array}$ & & $\begin{array}{l}3.866 \\
(1.22)\end{array}$ & & $\begin{array}{c}4.284^{\star \star \star} \\
(2.88)\end{array}$ & & $\begin{array}{l}2.169 \\
(1.14)\end{array}$ & & $\begin{array}{c}192.792 \\
(1.35)\end{array}$ & & $\begin{array}{l}0.189 \\
(0.81)\end{array}$ & & $\begin{array}{c}3.200^{\star \star \star} \\
(2.56)\end{array}$ \\
\hline Interaction PWC & & $\begin{array}{l}-8.623 \\
(-1.36)\end{array}$ & & $\begin{array}{c}-18.288^{* * *} \\
(-5.01)\end{array}$ & & $\begin{array}{c}-6.036^{\star * *} \\
(-3.43)\end{array}$ & & $\begin{array}{l}-1.511 \\
(-0.71)\end{array}$ & & $\begin{array}{c}-213.391 \\
(1.48)\end{array}$ & & $\begin{array}{l}0.367 \\
(1.40)\end{array}$ & & $\begin{array}{l}-3.529^{\star *} \\
(-2.51)\end{array}$ \\
\hline Interaction NYC & & $\begin{array}{l}-3.701 \\
(-0.86)\end{array}$ & & $\begin{array}{c}9.319^{\star \star \star} \\
(4.23)\end{array}$ & & $\begin{array}{c}3.040^{\star * *} \\
(2.90)\end{array}$ & & $\begin{array}{c}-3.045^{\star \star} \\
(-2.30)\end{array}$ & & $\begin{array}{c}112.218 \\
(1.34)\end{array}$ & & $\begin{array}{c}-0.340^{\star *} \\
(-2.00)\end{array}$ & & $\begin{array}{l}-1.581^{*} \\
(-1.81)\end{array}$ \\
\hline Interaction SP & & $\begin{array}{l}-6.021^{*} \\
(-1.88)\end{array}$ & & $\begin{array}{c}-4.887^{\star *} \\
(-2.36)\end{array}$ & & $\begin{array}{c}-5.392^{\star * *} \\
(-5.18)\end{array}$ & & $\begin{array}{l}0.789 \\
(0.62)\end{array}$ & & $\begin{array}{c}91.089 \\
(1.52)\end{array}$ & & $\begin{array}{l}0.144 \\
(0.91)\end{array}$ & & $\begin{array}{c}2.197^{\star \star \star} \\
(2.61)\end{array}$ \\
\hline Year 2008 & $\begin{array}{c}-9.635^{\star * *} \\
(-6.95)\end{array}$ & $\begin{array}{c}-9.729^{\star * *} \\
(-6.97)\end{array}$ & $\begin{array}{c}9.614^{\star \star *} \\
(9.99)\end{array}$ & $\begin{array}{c}8.901^{* * *} \\
(9.42)\end{array}$ & $\begin{array}{c}4.400^{\star * *} \\
(10.10)\end{array}$ & $\begin{array}{c}4.176^{\star \star \star} \\
(9.67)\end{array}$ & $\begin{array}{c}-11.351^{\star \star \star} \\
(-21.60)\end{array}$ & $\begin{array}{c}-11.269^{\star * *} \\
(-21.38)\end{array}$ & $\begin{array}{c}52.848 \\
(1.12)\end{array}$ & $\begin{array}{c}38.463 \\
(0.79)\end{array}$ & $\begin{array}{c}-0.205^{\star * *} \\
(-2.89)\end{array}$ & $\begin{array}{c}-0.189^{* * *} \\
(-2.67)\end{array}$ & $\begin{array}{c}4.855^{\star \star *} \\
(13.76)\end{array}$ & $\begin{array}{c}4.868^{\star \star *} \\
(13.83)\end{array}$ \\
\hline Constant & $\begin{array}{c}23.351^{* * *} \\
(8.09)\end{array}$ & $\begin{array}{c}22.888^{* * *} \\
(7.95)\end{array}$ & $\begin{array}{c}89.504^{* * *} \\
(59.97)\end{array}$ & $\begin{array}{c}88.090^{\star * *} \\
(59.96) \\
\end{array}$ & $\begin{array}{c}95.342^{\star * *} \\
(146.31)\end{array}$ & $\begin{array}{c}94.931^{* * *} \\
(147.05)\end{array}$ & $\begin{array}{c}49.237^{\star * *} \\
(44.41)\end{array}$ & $\begin{array}{c}49.384^{\star * \star} \\
(44.39) \\
\end{array}$ & $\begin{array}{c}-53.439 \\
(-0.77)\end{array}$ & $\begin{array}{r}-15.811 \\
(-0.23) \\
\end{array}$ & $\begin{array}{c}2.319^{\star * *} \\
(16.36)\end{array}$ & $\begin{array}{c}2.370^{* * *} \\
(16.66)\end{array}$ & $\begin{array}{c}57.926^{\star * *} \\
(109.64) \\
\end{array}$ & $\begin{array}{c}58.036^{\star * *} \\
(109.91)\end{array}$ \\
\hline $\begin{array}{l}\text { ATE } \\
\begin{array}{l}\text { F-test ( on } \\
\text { interaction } \\
\text { terms) }\end{array}\end{array}$ & & $\begin{array}{c}-3.933^{* * *} \\
(-3.62)\end{array}$ & & $\begin{array}{c}2.921^{* * *} \\
(4.42)\end{array}$ & & $\begin{array}{c}1.899^{\star * *} \\
(6.28)\end{array}$ & & $\begin{array}{c}-3.042^{\star \star \star} \\
(-8.18)\end{array}$ & & $\begin{array}{l}-34.567 \\
(-1.55)\end{array}$ & & $\begin{array}{c}-0.170^{\star * *} \\
(-3.50)\end{array}$ & & $\begin{array}{c}0.677^{\star * *} \\
(2.74)\end{array}$ \\
\hline Observations & 363 & 363 & 801 & 801 & 1,030 & 1,030 & 1,160 & 1,160 & 276 & 276 & 950 & 950 & 1,129 & 1,129 \\
\hline R-squared & 0.463 & 0.481 & 0.289 & 0.331 & 0.282 & 0.309 & 0.647 & 0.650 & 0.372 & 0.407 & 0.104 & 0.115 & 0.415 & 0.428 \\
\hline Countries & 95 & 95 & 107 & 107 & 113 & 113 & 116 & 116 & 109 & 109 & 95 & 95 & 114 & 114 \\
\hline
\end{tabular}

t-statistics in parentheses

${ }^{\star * \star} p<0.01,{ }^{* \star} p<0.05,{ }^{*} p<0.1$ 


\section{CONCLUSION}

If the goal of PRSPs is to translate the intentions of the MDGs, they appear to be having a positive effect, at least, according to the indicators examined in this paper. The PRSPs have played an important role implementing the MDG agenda by translating the development targets into country-specific strategies. On the evidence presented in this paper, it appears that countries under PRSP treatment are more effective at achieving better MDG outcomes than the comparison group of countries.

The inclusion of the paradigm alignment indices into the model seeks to overcome the problems associated with aggregate evaluation techniques suggested in Marshall and Walters (2011). PRSP content is also likely to drive progress towards the MDGs in addition to PRSP adoption. Paradigm alignment indices were devised using a scorecard approach which measured the degree of policy adoption to the WC, the PWC, the NYC and the SP agenda. These policy choices were evaluated by scorecard techniques and the creation of a paradigm alignment index which aggregates scores. It is difficult to monitor the extent to which PRSP policies are implemented, and this study assumes that countries did not experience any slippage.

This study uses propensity score matching techniques and fixed effect panel estimations to analyse the impact of PRSP treatment on the following MDG outcomes: headcount poverty; infant mortality; primary school enrolment; ratio of girls to boys in primary school; maternal mortality; HIV prevalence; and access to sanitation.

Encouragingly, this study finds positive PRSP treatment effects in all the MDG indicators examined. Furthermore, of all the paradigm indices those countries aligned to 
the NYC under PRSP treatment achieve results that improve outcomes for all MDG indicators with the exception of sanitation and headcount poverty. However, a PRSPs alignment to a SP agenda does not have statistically significant effects on reducing headcount poverty. These results are evidence of how the ambitious targets of the MDGs used in combination with the practicalities of the PRSPs are able to deliver the intended objective of multi-dimensional poverty reduction.

As a caveat, the propensity score matching techniques were only able to match 52 of the 58 countries. As is the way with development data, the availability of country level data is constrained by the administrative capacity of those countries to collect it.

This study is timely. The international community is currently in the process of setting the post-2015 development agenda and finalising a set of Sustainable Development Goals (SDGs) to replace the MDGs. The proposed SDGs comprise 17 major goals and 169 targets. They represent transformative goals with expanded focus on equity, development, and climate change (United Nations, 2014). While, this study finds that the plans outlined in the PRSPs are effective at spurring progress towards the MDGs, the need to have clearly outlined national development strategies is heightened by the ambition and number of the SDGs. 


\section{APPENDIX}

Table A1: Variable Definitions and Sources

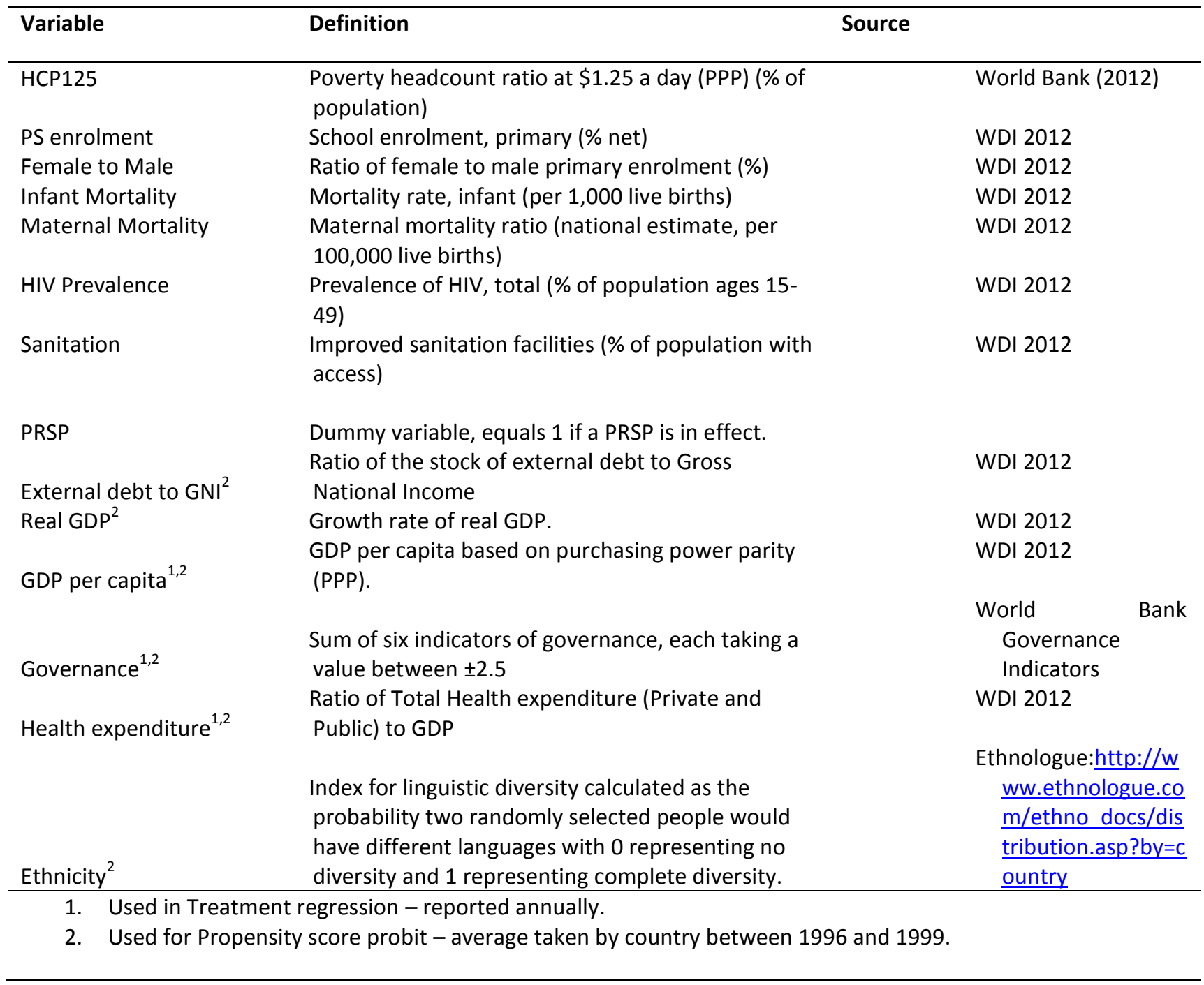


Table A2: Washington Consensus Policies

Washington Consensus Washington Consensus Policies
Components

\begin{tabular}{|c|c|}
\hline Fiscal discipline & 1.Limiting budgetary expenditure - mention of prudent policy* \\
\hline $\begin{array}{l}\text { Reorientation of public } \\
\text { expenditures }\end{array}$ & $\begin{array}{l}\text { 2.Increased spending on capital expenditure - infrastructure** } \\
\text { 3.Increased expenditure on basic social services** } \\
\text { 4. Relocation of public expenditure to pro-poor programs }\end{array}$ \\
\hline Tax reform & $\begin{array}{l}\text { 5.Increased revenue through tax reform** } \\
6 . \text { Broad-based consumption tax* }\end{array}$ \\
\hline $\begin{array}{l}\text { Financial liberalisation/interest } \\
\text { rates }\end{array}$ & $\begin{array}{l}\text { 7.Market determined interest rates* } \\
\text { 8.Capital account convertibility*** } \\
\text { 9.Prudent monetary policy towards price stability*** }\end{array}$ \\
\hline $\begin{array}{l}\text { Unified and competitive } \\
\text { exchange rate }\end{array}$ & $\begin{array}{l}\text { 10. Exchange rate floating* } \\
\text { 11. Elimination of exchange rate controls** }\end{array}$ \\
\hline Trade liberalisation & $\begin{array}{l}\text { 12. Elimination of quotas / import licensing } * * \\
\text { 13. Reduced tariffs** } \\
\text { 14. Reduced customs regulations } * *\end{array}$ \\
\hline $\begin{array}{l}\text { Openness to Foreign Direct } \\
\text { Investment }\end{array}$ & $\begin{array}{l}\text { 15. Investment deregulation* } \\
\text { 16. Legislation to allow inflows of foreign investment** }\end{array}$ \\
\hline Privatisation & 17. Privatisation of government owned industries * \\
\hline Deregulation & $\begin{array}{l}\text { 18. Reduction in the controls on the establishment of new firms and on } \\
\text { new investment* } \\
\text { 19. Elimination of price controls*** }\end{array}$ \\
\hline Secure property rights & 20. Legislation of Property Rights* \\
\hline
\end{tabular}

* Williamson's (1998) original tenet

** disaggregated (sub) policy of original tenet

*** not included in Williamson (1998) original tenet - but included with Washington institution's version

of consensus (Marangos, 2009). 
Table A3: Post-Washington Consensus Policies

\begin{tabular}{ll}
\hline PWC Components & PWC Policies \\
\hline Corporate Governance & 1. Bankruptcy law $* *$ \\
& 2. Effective competition law ** \\
Anti-corruption & 3. National anti-corruption strategies ** \\
& 4. Public administration reform ** \\
Flexible labour markets & 5. Judicial reform** \\
WTO agreements & 6. Labour market reform legislation ** \\
Financial codes and standards & 7. Flexible labour market ** \\
Prudent capital account opening & 8. Commitment to the WTO principles outlined* \\
Non-intermediate exchange rate & 9. Prudential requirement ratios stipulated and enforced* \\
& 10. Capital account prudence* \\
Independent central banks & 11. Target zones for exchange rate** \\
inflation targeting & 12. Crawling bands** \\
Social safety nets & 13. Independence of the central bank*
\end{tabular}

Targeted poverty reduction

17. Rank poverty programs in relative importance with economic and redistribution criteria*

\footnotetext{
*Rodrik (2006) original tenet

**Disaggregated (sub) policies
} 
Table A4: New York Consensus Policies

\begin{tabular}{|c|c|}
\hline NYC Components & NYC Polices \\
\hline Infrastructure capacity & $\begin{array}{l}\text { 1. Increased spending on capital expenditure - in areas of transport, } \\
\text { energy, water supply, sanitation and telecommunications** }\end{array}$ \\
\hline \multirow[t]{3}{*}{ Rural development } & $\begin{array}{l}\text { 2. Agricultural productivity - soil health; water management; farm } \\
\text { diversification and pest control* }\end{array}$ \\
\hline & $\begin{array}{l}\text { 3. Linking farmers to markets: storage; market places and agro } \\
\text { processing* }\end{array}$ \\
\hline & $\begin{array}{l}\text { 4. Evidence of irrigation techniques and water resource management; } \\
\text { pumps; drip irrigation; wells* }\end{array}$ \\
\hline \multirow[t]{2}{*}{ Education } & $\begin{array}{l}\text { 5. Primary school enrolment: elimination of school fees; provision of } \\
\text { school materials; cash transfers to parents* }\end{array}$ \\
\hline & 6. Gender participation addressed in schools* \\
\hline \multirow[t]{3}{*}{ Health } & $\begin{array}{l}\text { 7. Child mortality policies; neonatal immunisations; preventative } \\
\text { approaches to childhood illness (e.g.| malaria beds)* }\end{array}$ \\
\hline & $\begin{array}{l}\text { 8. maternal health policies; emergency obstetric care; skilled birth } \\
\text { attendance and antenatal care* }\end{array}$ \\
\hline & $\begin{array}{l}\text { 9. Prevention and control programmes for HIV/Aids, malaria and other } \\
\text { diseases * }\end{array}$ \\
\hline \multirow{4}{*}{$\begin{array}{l}\text { Governance - rule of law, } \\
\text { corruption }\end{array}$} & 10. National anti-corruption surveys** \\
\hline & 11. public expenditure tracking and review** \\
\hline & $\begin{array}{l}\text { 12. Government accountability programmes: civil liberties; political } \\
\text { rights; voice and accountability** }\end{array}$ \\
\hline & 13. human rights policies** \\
\hline \multirow[t]{2}{*}{ Employment } & 14. Public works programmes* \\
\hline & 15. Employment in decent work programmes* \\
\hline \multirow[t]{2}{*}{ Water and sanitation } & 16. Provide, operate and maintain water infrastructure* \\
\hline & 17. Construction and operation sanitation facilities* \\
\hline \multirow{2}{*}{$\begin{array}{l}\text { Gender equality and } \\
\text { empowerment }\end{array}$} & 18. Women's political representation* \\
\hline & 19. Reform to legislation for women's entitlement to land* \\
\hline \multirow[t]{2}{*}{ Environment } & $\begin{array}{l}\text { 20. Natural resource protection programmes; market mechanisms, } \\
\text { regulation and enforcement and Bio-diversity programmes* }\end{array}$ \\
\hline & $\begin{array}{l}\text { 21. Urban planning and investment to improve the lives of slum- } \\
\text { dweller* }\end{array}$ \\
\hline Science and Technology & $\begin{array}{l}\text { 22. Programmes to support research and development through higher } \\
\text { education; improved access to communication technologies* }\end{array}$ \\
\hline
\end{tabular}


Table A5: Social Protection Policies

\begin{tabular}{|c|c|}
\hline Social Protection Components & Social Protection Policies \\
\hline Social Assistance Policies & $\begin{array}{l}\text { 1. Cash-in-kind transfers agricultural inputs, shelter, non-food } \\
\text { items** } \\
\text { 2. Subsidies for housing, energy, and food** } \\
\text { 3. Educational assistance Scholarships* } \\
\text { 4. Fee waivers for essential services** } \\
\text { 5. Disaster relief programmes - funds for emergency relief or post- } \\
\text { emergency transitions** } \\
\text { 6. Disaster relief programmes - funds for emergency relief or post- } \\
\text { 7. Programmes for vulnerable groups: the elderly, disabled widows } \\
\text { 8. Programmes for the internally displaced: migrants and refugees** }\end{array}$ \\
\hline Social Insurance Policies & $\begin{array}{l}\text { 9. Unemployment insurance* } \\
\text { 10. Unconditional unemployment payments** } \\
\text { 11. Health/sickness insurance* } \\
\text { 12. Non-contributory pension schemes** } \\
\text { 13. Contributory pension schemes } \\
\text { 14. Disability pensions* } \\
\text { 15. Maternity allowances } \\
\text { 16. Industrial injury payments* }\end{array}$ \\
\hline Labour Market Programs & $\begin{array}{l}\text { 17. Labour market legislation to protect labour rights*** } \\
\text { 18. Child labour protection - labour code } * * * \\
\text { 19. Minimum Wage } * * * \\
\text { 20. employment promotion, matching people to jobs*** }\end{array}$ \\
\hline Additional Components & $\begin{array}{l}\text { 21. Priority or pillar for social protection in the PRSP } \\
\text { 22. Micro-finance* }\end{array}$ \\
\hline
\end{tabular}

*Baulch et al (2006) ** Farrington (2006) ***Sabates-Wheeler \& Devereux (2004) 
Table A6: Result from Propensity Score Matching

\begin{tabular}{ll}
\hline Variables & \\
\hline External debt to GNI & $0.005^{*}$ \\
& $(1.68)$ \\
Real GDP & 0.059 \\
& $(1.39)$ \\
GDP per capita & $-0.001^{* * *}$ \\
& $(-2.92)$ \\
Governance & 0.070 \\
& $(1.20)$ \\
Health expenditure to GDP & -0.0003 \\
& $(-0.10)$ \\
Ethnic diversity & $-0.99 *$ \\
& $(-1.77)$ \\
Constant & $1.445^{* *}$ \\
& $(2.33)$ \\
\hline Observations & 121 \\
Quasi-R & \\
\hline z-statistics in parentheses & 0.424 \\
$* * * p<0.01, * *$ p $<0.05, * 0.1$ &
\end{tabular}


Table A7: Treatment and Control Countries

\begin{tabular}{|c|c|c|c|}
\hline \multicolumn{2}{|l|}{ Treated Countries } & \multicolumn{2}{|l|}{ Control Countries } \\
\hline Albania & Lao PDR & Algeria & Macedonia, FYR \\
\hline Armenia & Lesotho & Angola & Malaysia \\
\hline Azerbaijan & Madagascar & Argentina & Mauritius \\
\hline Bangladesh & Malawi & Belarus & Mexico \\
\hline Benin & Maldives & Belize & Morocco \\
\hline Bhutan & Mali & Botswana & Panama \\
\hline Bolivia & Mauritania & Brazil & Papua New Guinea \\
\hline Burkina Faso & Moldova & Bulgaria & Paraguay \\
\hline Burundi & Mongolia & Central African Republic & Peru \\
\hline Cambodia & Nepal & Chile & Philippines \\
\hline Cameroon & Nicaragua & China & Russian Federation \\
\hline Cape Verde & Niger & Colombia & Samoa \\
\hline Chad & Nigeria & Comoros & Seychelles \\
\hline Congo, Rep. & Pakistan & Costa Rica & Solomon Islands \\
\hline Djibouti & Rwanda & Cote d'Ivoire & South Africa \\
\hline Dominica & Senegal & Dominican Republic & St. Kitts and Nevis \\
\hline Ethiopia & Serbia & Ecuador & St. Lucia \\
\hline Gambia, The & Sierra Leone & Egypt, Arab Rep. & St. Vincent and Grenadines \\
\hline Georgia & Sri Lanka & El Salvador & Sudan \\
\hline Ghana & Tajikistan & Eritrea & Swaziland \\
\hline Guinea & Tanzania & Fiji & Syrian Arab Republic \\
\hline Guyana & Uganda & Gabon & Thailand \\
\hline Haiti & Uzbekistan & Grenada & Togo \\
\hline Honduras & Vietnam & Guatemala & Tonga \\
\hline Kenya & Yemen, Rep. & India & Tunisia \\
\hline Kyrgyz Republic & Zambia & Indonesia & Turkey \\
\hline & & Iran, Islamic Rep. & Turkmenistan \\
\hline & & Jamaica & Ukraine \\
\hline & & Jordan & Uruguay \\
\hline & & Kazakhstan & Vanuatu \\
\hline & & Latvia & Venezuela, \\
\hline & & Lebanon & Zimbabwe \\
\hline & & Lithuania & \\
\hline 52 treated countries & & 65 control countries & \\
\hline
\end{tabular}


Table A8: Descriptive Statistics for Control Countries

\begin{tabular}{lllllll}
\hline Variable & N & Mean & S.D. & Min & Median & Max \\
\hline Dependent Variables & & & & & & \\
\hline hcp125 & 229 & 8.69 & 11.31 & 0 & 5.32 & 62.9 \\
PS enrolment & 441 & 89.58 & 11.09 & 33 & 92 & 99.9 \\
Female to male & 569 & 95.29 & 6.19 & 66.3 & 97.2 & 104 \\
Infant mortality & 650 & 30.62 & 24.11 & 5.3 & 20.85 & 121 \\
Maternal mort & 164 & 108.61 & 181.15 & 0 & 45.95 & 1100 \\
HIV prevalence & 490 & 2.69 & 6.06 & 0.1 & 0.45 & 26.3 \\
Sanitation & 621 & 72.46 & 24.87 & 11 & 80 & 100 \\
\hline Explanatory Variables & & & & & & \\
Ethnicity & 650 & 0.42 & 0.32 & 0 & .45 & .99 \\
GDP per capita & 640 & 6.79 & 3.95 & 0.49 & 6.53 & 21 \\
Real GDP & 650 & 4.33 & 4.61 & -17.7 & 4.48 & 22.6 \\
Governance & 650 & -1.72 & 3.86 & -10 & -1.94 & 7.49 \\
Health \% GDP & 643 & 5.49 & 1.82 & 0.01 & 5.4 & 11.2 \\
\hline
\end{tabular}

Table A9: Descriptive Statistics for Treated Countries

\begin{tabular}{lllllll}
\hline Variable & N & Mean & S.D. & Min & Median & Max \\
\hline Dependent Variables & & & & & & \\
\hline hcp125 & 134 & $28.41^{* * *}$ & 22.18 & 0 & 22.3 & 84.6 \\
PS enrolment & 360 & $76.19 * * *$ & 18.95 & 26.3 & 81.4 & 99.8 \\
Female to Male & 461 & $91.50^{* * *}$ & 10.86 & 55.8 & 96.1 & 108 \\
Infant mortality & 520 & $59.89 * * *$ & 28.84 & 7 & 61.9 & 146 \\
Maternal mort & 116 & $301.05^{* * *}$ & 336.07 & 0 & 122 & 1800 \\
HIV prevalence & 470 & 2.55 & 4.41 & 0.1 & 0.85 & 24.5 \\
Sanitation & 518 & $46.40^{* * *}$ & 28.17 & 7 & 46 & 100 \\
\hline Explanatory Variables & & & & & & \\
Ethnicity & 490 & $0.58^{* * *}$ & 0.29 & 0.002 & 0.64 & 0.97 \\
GDP per capita & 520 & $2.17^{* * *}$ & 1.81 & 0.42 & 1.65 & 11 \\
Real GDP & 520 & $5.39 * * *$ & 4.80 & -15.7 & 5.39 & 37.8 \\
Governance & 520 & $-3.58^{* * *}$ & 2.75 & -9.71 & -3.44 & 4.79 \\
Health \% GDP & 520 & $5.80^{* * *}$ & 2.02 & 2.11 & 5.62 & 15.6 \\
\hline$* * *$ : 1\% significance level in test of differences of means with control group. \\
\hline
\end{tabular}




\section{REFERENCES}

ANGRIST, J. D. \& PISCHKE, J. S. 2009. Mostly Harmless Econometrics: An Empiricist's Campanion, Princeton, New Jersey, Princeton University Press.

BAULCH, B. \& WOOD, J. 2008. Social Protection Index for Committed Poverty Reduction, Manila, Asian Development Bank.

BAULCH, B., WOOD,. J. \& WEBER, A. 2006. Developing a Social Protection Index for Asia. Development Policy Review, 24, 5-29.

BOJO, J. \& REDDY, R. C. 2002. Status and Evolution of Environmental Priorities in the Poverty Reduction Strategies. Environmental Economics Series Paper No. 93, Washington DC. [Online].

BOOTH, D. 2005. Missing Links in the Politics of Development:Learning from the PRSP Experiment. London: Overseas Development Institute.

CHABÉ-FERRET, S. 2015. Analysis of the bias of Matching and Difference-in-Difference under alternative earnings and selection processes. Journal of Econometrics, 185, 110-123.

CHERU, F. 2006. Building and Supporting PRSPs in Africa: what has worked well so fare? What needs changing? Third World Quarterly 27, 335-376.

CLUMP, R. K. V., HOTZ, J., IMBENS, G. \& MITNIK, O. A. 2009. Dealing with limited overlap in estimation of average treatment effects. Biometrica, 96, 187-199.

CORNWALL, A. \& BROCK, K. 2005. What do buzzwords do for development policy? A critical look at 'participation', 'empowerment' and 'poverty reduction'. Third World Quarterly, 26, 1043-1060.

DEVERAUX, S. \& SABATES-WHEELER, R. 2004. Transformative Social Protection. IDS Working Paper [Online], 232. 
DIJKSTRA, G. 2005. The PRSP Approach and the Illusion of Improved Aid Effectiveness: Lessons from Bolivia, Honduras and Nicaragua. Development Policy Review, 23, 443-464.

DRISCOLL, R. \& EVANS, A. 2005. Second-Generation Poverty Reduction Strategies: New Opportunities and Emerging Issues. Development Policy Review, 23, 5-25.

EGgEN, A. R. \& BEZEMER, D. J. 2008. Do Poverty Reduction Strategy Papers Help Achieve the Millennium Development Goals?' "Cooperation of International Institutions for Related Global Issues" [Online], 7030. [Accessed February 2008].

ELKINS, M. 2014. Emedding the Vulnerable into the Millennium Development Goals: Social Protection in Poverty Reduction Strategy Papers. Journal of International Development, $26,853-874$.

ELKINS, M. \& FEENY, S. 2014. Policies in Poverty Reduction Strategy Papers: dominance or diversity? Canadian Journal of Development Studies / Revue canadienne d'études du développement, 35, 228-248.

FARRINGTON, J., \& SLATER, R. 2006. Introduction: Cash Transfers: Panacea for Poverty Reduction or Money Down the Drain? Development Policy Review, 24, 499-624.

FINE, B. 2002. Economic Imperialism and the New Development Economics as a Paradigm Shift. World Development 30, 2057-2070.

FUKUDA-PARR, S. 2003. The Human Development Paradigm: Operationalizing Sen's Ideas on Capabilities. Feminist Economics, 9, 301-317.

FUKUDA-PARR, S. 2010. Reducing Inequality - The Missing MDG: A Content Review of PRSPs and Bilateral Donor Statements. IDS Bulletin, 41, 26-35

FUKUDA-PARR, S., GREENSTEIN J., \& STEWART, D. 2013. How Should MDG success and Failure be Judged: Faster Progress or Achieving Targets. World Development, 41, 19-30.

GOTTSCHALK, R. 2005. The Macro Content of PRSPs: Assessing the Need for a More Flexible Macroeconomic Policy Framework. Development Policy Review, 23, 419-442. 
HECKMAN, J., ICHIMURA, H. \& TODD, P. 1997. Matching as an Econometric Evaluation Estimator: Evidence fromEvaluating a Job Training Programme. Review of Economic Studies, 64, 605654.

HIJZEN, A., MARTINS, P. S., SCHANK, T. \& UPWARD, R. 2013. Foreign-owned firms around the world: A comparative analysis of wages and employment at the micro-level,. European Economic Review, 60, 170-188.

HIJZEN, A., UPWARD, R. \& WRIGHT, P. W. 2010. The Income Losses of Displaced Workers. Journal of Human Resources, 45, 243-269.

HONG, S. H. 2013. Measuring the effect of Napster on recorded music sales: difference-indifference estimates under compositional changes. Journal of Applied Econometrics, 28, 297-324.

HULME, D. \& SCOTT, D. 2010. The Political Economy of the MDGs: Retrospect and Prospect for the World's Biggest Promise. Brooks World Poverty Institute [Online].

IKHIDE, S. I. \& OBANDAN, M. I. 2011. The next generation of Poverty Reduction Strategy Papers in Africa: What is the Role for Capacity Building. Poverty and Public Policy, 3.

IMBENS, G. W. \& WOOLDRIDGE, J. M. 2009. Recent Developments in the econometrics of program evaluation. Journal of Economic Literature, 47, 5-86.

KAMRUZZMAN, P. 2009. Poverty Reduction Strategy Papers and the rhetoric of participation. Development in Practice, 19, 61-71.

KENNY, C. \& SUMNER, A. 2011. More Money or More Development: What Have the MDGs Achieved? , CGD Working Paper 278.

KLASEN, S. \& LANGE, S. 2012. Getting Progress Right: Measuring Progress Towards the MDGS Against Historical Trends. Courant Research Centre Discussion Paper 87 [Online].

LAZARUS, J. 2008. Participation in Poverty Reduction Strategy Papers: reviewing the past, assessing the present and predicting the future. Third World Quarterly, 29, , 1205-1221. 
LECHNER, M. 2010. The Estimation of Causal Effects by Difference-in-Difference Methods. Foundations and Trends in Econometrics, 4, 165-224.

LEO, B. \& BARMEIER, J. 2010. Who Are the MDG Trailblazers? A New MDG Progress Index. CDG Working Paper 222.

MACHIN, S., MCNALLY, S. \& MEGHIR, C. 2010. Resources and standards in urban school. Journal of Human Capital, 4, 365-393

MARANGOS, J. 2009. What happened to the Washington Consensus? The evolution of International development policy. The Journal of Socio-Economics, 38, 197-208.

MARSHALL, R. \& WALTERS, B. 2011. Evaluating ten years of 'strategizing' for poverty reduction: A cross-sectional appraisal of the Poverty Reduction Strategy (PRSP) initiative. Brooks World Poverty Institute, PWPI Working Paper 143.

MOSELY, P. 2001. Attacking Poverty and the Post Washington Consensus. Journal of International Development, 13307 - 313.

RODRIK, D. 2006. Goodbye Washington Consensus, Hello Washington Confusion? A Review of the World Bank's Economic Growth of the 990's: Learning from a Decade of Reform. Journal of Economic Literature, 44, 973-987.

SAAD-FILHO, A. 2007. Life beyond the Washington Consensus: An introduction to Pro-poor Macroeconomic Policies. Review of Political Economy, 19, 513-537.

SAPKOTA, B. J. 2011. Mainstreaming globalisation in Poverty Reduction Strategy Papers in the Asia-Pacific region. Development in Practice, 21.

STEWART, F. \& WANG, M. 2003. Do PRSPs empower poor countries and disempower the World Bank, or is it the other way around? Queen Elizabeth House Working Paper [Online], 108. [Accessed October 2003].

STIGLITZ., J. 1998. "More Instruments and Broader Goals: Moving Toward the Post-Washington Consensus". The WIDER Annual Lecture. Helsinki: WIDER. 
SUMNER, A. 2006. In Search of the Post-Washington (Dis)Consensus: the 'missing' content of PRSPs. Third World Quarterly, 27, 1401-1412.

UNDP. 2005. Investing In Development: A Practical Plan to Achieve the Millennium Development Goals, New York, UN Millennium Project.

UNITED NATIONS 2014. The Road to Dignity by 2030: Ending Poverty, Transforming All Lives and Protecting the Planet. Synthesis Report of the Secretary-General on the Post-2015 Agenda. New York: United Nations.

VANDEMOORTELE., J. 2009. The MDG Conundrum: Meeting the Targets without Missing the Point. Development Policy Review, 27, 355-371.

WILLIAMSON, J. 1990. What Washington means by policy reform In: WILLIAMSON, J. (ed.) Latin American adjustment: how much has happened Washington DC.

WILLIAMSON, J. 1993. Democracy and the 'Washington Consensus'. World Development, 21, $1329-1336$. 